\title{
Dead Wood as an Element Enriching Biodiversity of Forest Ecosystems: A Case Study Based on Mites from the Suborder Uropodina (Acari: Parasitiformes)
}

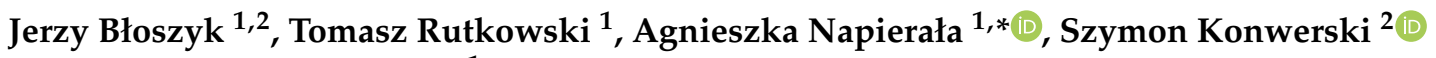 \\ and Michał Zacharyasiewicz ${ }^{1}$ \\ 1 Department of General Zoology, Faculty of Biology, Adam Mickiewicz University, Uniwersytetu \\ Poznańskiego 6, 61-614 Poznań, Poland; bloszyk@gmail.com (J.B.); tomasz.rutkowski@amu.edu.pl (T.R.); \\ zacharyasiewicz@amu.edu.pl (M.Z.) \\ 2 Natural History Collections, Faculty of Biology, Adam Mickiewicz University, Uniwersytetu Poznańskiego 6, \\ 61-614 Poznań, Poland; szymkonw@amu.edu.pl \\ * Correspondence: agan@amu.edu.pl
}

check for updates

Citation: Błoszyk, J.; Rutkowski, T.; Napierała, A.; Konwerski, S.; Zacharyasiewicz, M. Dead Wood as an Element Enriching Biodiversity of Forest Ecosystems: A Case Study Based on Mites from the Suborder Uropodina (Acari: Parasitiformes). Diversity 2021, 13, 476. https:/ / doi.org/10.3390/d13100476

Academic Editor: Anna Seniczak

Received: 27 August 2021

Accepted: 25 September 2021

Published: 29 September 2021

Publisher's Note: MDPI stays neutral with regard to jurisdictional claims in published maps and institutional affiliations.

Copyright: (c) 2021 by the authors. Licensee MDPI, Basel, Switzerland. This article is an open access article distributed under the terms and conditions of the Creative Commons Attribution (CC BY) license (https:/ / creativecommons.org/licenses/by/ $4.0 /)$.

\begin{abstract}
The importance of dead wood in forest ecosystems for the existence of invertebrates has been widely discussed in the literature. The major aim of this study is to test the hypothesis that the presence of dead wood in forests considerably increases the species diversity of Uropodina (Acari: Parasitiformes) communities in a given area. The areas selected for the study are unique from a natural point of view. They are the Białowieża Primeval Forest, Cisy Staropolskie im. Leona Wyczółkowskiego Nature Reserve, and five oak-hornbeam nature reserves in western Poland. The study is based on materials collected since the 1960s of the last century. The highest number of species (37) both in soil and dead wood microhabitats was recorded in the Białowieża Primeval Forest and Cisy Staropolskie Nature Reserve, though the dead wood material from the second area contained the highest number of species (33). The results of the analysis show that the presence of dead wood increases species diversity of Uropodina communities in all locations under scrutiny. Moreover, dead wood increases the species diversity of Uropodina communities by attracting rare and stenotopic species, and therefore leaving dead trees in forests is extremely important for the habitat protection of these species.
\end{abstract}

Keywords: merocenoses; Mesostigmata; national park; nature reserve; phoresy; dead wood; saproxylic invertebrates; species richness; unstable microhabitats

\section{Introduction}

The common term "dead wood" used to describe unstable microhabitat explicitly suggests that this type of habitat results from the death of trees in a forest, which can be a natural process or caused by human activities. In the case of the latter, it can be either direct and deliberate human activity, which often means cutting down of trees, or different indirect activities which cause gradual death of tree stands, for example, extensive drainage of lands, environmental pollution, etc. Tree cutting and fragmentation of forest ecosystems are not the only factors that have an impact on the overall decrease in the biodiversity of forest mesofauna. Besides this, forest management is also very important as it often consists in removing dead wood from forests, which can be observed in commercial forests [1], or leaving it permanently, such as in the case of nature reserves and national parks [1-5]. According to the final report of the National Forest Inventory in Poland for the period 2016-2020 [6], the thickness of dead wood in standing and lying trees and the number of stumps of coniferous trees per a given unit of area measurement are the highest in national parks. Special attention should also be paid to the recent heavy storms and tornadoes observed in the past few years, which are the result of the progressive global 
climate changes, often causing considerable destruction of tree stands (windthrow) in large areas. In such cases, foresters usually dispose of the whole trees felled by the wind, with the exception of legally protected areas (i.e., national parks and nature reserves), where the legal regulations do not allow to do so.

Merocenoses of dead wood constitutes diverse and unstable microhabitats, which occur in different forest complexes, in a different number, and in different types. Different types of these microhabitats occur most often in large numbers in legally protected forests, where human interference is very slight. The lowest number of such microhabitats is in forests with intensive human activity aimed at gaining large quantities of wood. Merocenoses of dead wood occurs in the form of lying logs, rootstocks, windthrows, stumps of cut-down trees, broken trunks (also called windsnap-standing fragments of a broken tree bole), and decaying (usually at the base roots) alive trees (see Tables). A different type of such microhabitats are tree hollows, which can be the results of mechanical damages or inner rotting of wood, or they simply can be excavated by woodpeckers. Each of these microhabitats is in fact a different niche for invertebrates with the different scale of difficulty of accessibility, and where the environmental conditions change with time due to the gradual decay of wood.

Many recent studies put a lot of emphasis on the great importance of dead wood in forest ecosystems (see e.g., [7-11]). It was proved that leaving lying logs, broken trunks, and stumps considerably increases the number of niches inhabited by invertebrates [6-10]. Both the quantity and type of dead wood left in forests have an impact on species diversity and abundance of the invertebrates inhabiting the area $[7,8]$. The high importance of dead wood merocenoses was proved so far mainly in the case of saproxylic insects [12]. The presence of dead wood increases the biodiversity of saproxylic species of Coleoptera and Diptera feeding on dead wood [13,14], as well as many other invertebrates, including centipedes, snails, terrestrial crustaceans and arachnids [7]. Decaying wood has an influence on the decomposer communities such as bryophytes, fungi, and mites [9,15,16]. Among the decomposer organisms, Oribatida and Mesostigmata are very important. Many oribatids feed on fungal hyphae, lichens, mosses, and dead plant matter [17,18]. Mesostigmata are mostly predators, feeding on nematodes, collembolans, eggs, and larvae of Diptera [19-21]. Uropodina (Acari: Parasitiformes) belong to the Mesostigmata inhabiting dead wood. The highest abundance of these mites was observed in areas with a high content of organic matter, for example, litter in deciduous forests, (abundance up to 10,000 ind./ $\mathrm{m}^{2}$ ), including dead wood and compost [22,23]. These mites differ as to their trophic preferences. Many of them are predators and some are also saprophagous species, which feed on dead organic matter from plants and animals [20]. Others are mycetophagous species, feeding on spores and mycelia [24,25].

In the first phase of wood decay mites, just like other invertebrates, colonize the surface of the felled tree or stump and the strata beneath the bark (if the tree or stump still has any bark) $[26,27]$. In the course of time, the process of wood decay proceeds and produces more and more dead wood, which becomes the major habitat for mites. Species diversity and abundance of Uropodina, just like other invertebrates, depends on the extent of wood decay and wood humidity. The high degree of humidity considerably accelerates the pace of wood decay, whereas dry conditions slow down this process. Furthermore, the wood of different tree species decays in different ways, and hence different mite species have different habitat preferences in this respect $[3,4,28]$.

Due to their small size and limited capabilities of self-mobility, Uropodina has certain difficulties with the colonization of dead wood merocenoses and tree hollows. In the case of tree trunks lying directly on the ground and stumps the process of moving from soil to the new habitat is fairly easy. It is more problematic for stenotopic species, which live mainly in dead wood merocenoses. The dispersion of these species proceeds with the changes of the environmental conditions, that is, the proceeding wood decay and therefore gradual loss of the unstable merocenoses (the process of wood decay of a lying tree trunk or stump can last a few years or even a few hundred years). Most Uropodina species inhabiting dead 
wood can disperse passively (phoresy) by using insects (especially beetles), and centipedes, as vectors. The phenomenon of phoresy in Uropodina mites is thoroughly discussed in many studies [29-37]. One of the evolutionary adaptations of Uropodina mites to phoresy is the development of a pedicel in deutonymphs (the migratory form), which they use to attach to the body of the vector. In this way, deutonymphs can disperse over a considerable distance to find and colonize the right microhabitat. Mites can be very abundant, sparse in number, or occasional on different parts of the insect (Appendix A Figure A1).

The importance of dead wood for Uropodina communities has not been thoroughly analyzed yet. The only studies that discuss this problem, but focusing on Mesostigmata, are those published by Huhta et al. [1]. The authors of the current study present in this article the results of their long-term observations of mites from the suborder Uropodina inhabiting merocenoses of dead wood examined in a few forest complexes in Poland. The major aim of this study was to test the hypothesis saying that the presence of dead wood in forests can have a significant impact on species diversity of Uropodina communities in the examined area. The areas of uniquely high natural value were deliberately selected for the study because they retain the highest degree of biodiversity. Among such areas, there are the Białowieża Primeval Forest, which is the last largest natural forest complex in Europe [38-41], Cisy Staropolskie im. Leona Wyczółkowskiego Nature Reserve, in which the largest population of the common yew (Taxus baccata L.) in Europe has been protected for over 160 years [42-44], and some nature reserves in Wielkopolska (Greater Poland).

\section{Materials and Methods}

The research was conducted in seven legally protected areas located in different regions of Poland: the Białowieża Primeval Forest, and six nature reserves: Cisy Staropolskie im Leona Wyczółkowskiego, Jakubowo, Las Grądowy near Mogilnica, Bytyńskie Brzęki, Brzęki near Stara Gajówka, and Huby Grzebieniskie (Table 1). The detailed descriptions of the study areas were published in earlier publications [4,45-47].

The analyzed material contains 7529 samples, out of which 6696 come from litter and soil and 833 from different types of dead wood merocenoses. The samples were collected in different periods of time and by different researchers (Table 1). The soil samples were sievings of litter and quantitative samples were taken with a biocenometre $\left(16-30 \mathrm{~cm}^{2}\right.$ to the depth of $10 \mathrm{~cm}$ ). The latter were more frequently taken in the nature reserves. The samples from the dead wood merocenoses and tree hollows contained unsieved dead wood with a volume between 0.5 and 0.8 litres. The samples were extracted for 36-48 $\mathrm{h}$ (depending on the humidity) with Tullgren funnels, and then the extracted specimens were preserved in 75\% ethyl alcohol. The mites were sorted out from the samples with a stereoscopic microscope and then identified, after they had been cleared in $80 \%$ lactic acid by means of an Olympus BX51. The specimens were identified using the morphological criteria from the original descriptions and later accounts [30,48-51]. The identification of the species was carried out by the first author. The analyzed material was deposited in the Natural History Collections at the Faculty of Biology at AMU in Poznan. The obtained data were stored in a computer database AMUNATCOLL. The illustrations of phoresy (Figure A1) were made with scanning electron microscopy (SEM) techniques. Beetles and mites were air-dried, put on a pin stub with double-sided sticky tape, coated with gold and observed in a Zeiss Evo 40 Scanning Electron Microscope.

Due to the fact that the number of the samples collected in each area is different (however, the number of the samples is very high in each area), the structure of the analyzed mite communities is illustrated with a scale of dominance (D), and the frequency of occurrence $(\mathrm{F})$. The scale has the following classes: dominance D5 eudominants $(>30 \%)$, D4 dominants (15.1-30.0\%), D3 subdominants (7.1-15.0\%), D2 recedents $(3.0-7.0 \%)$ and D1 subrecedents $(<3 \%)$; frequency F5 euconstants $(>50 \%)$, F4 constants $(30.1-50 \%)$, F3 subconstants (15.1-30.0\%), F2 accessory species (5.0-15.0\%) and F1 accidents $(<5 \%)$ [30]. The species listed in the tabulations (Table A1, Table 2) were arranged according to their frequency in the studied areas. The community similarity of the species 
composition for Uropodina mites inhabiting the merocenoses of dead wood in the studied areas was calculated by means of the Marczewski-Steinhaus species similarity index: $\mathrm{S}=\mathrm{c} /(\mathrm{a}+\mathrm{b}-\mathrm{c})$, where $\mathrm{c}$ is the number of species present in both compared communities, and $a$ and $b$ stand for the total numbers of species in each community [52]. The full joining analysis, which uses the most distant neighbors, was used to prepare the dendrogram. The obtained results are given as percentages. The analyses were performed with AnalizaTor 2.0 software.

A few years ago, Kuberski et al. [53] estimated the amount of dead wood in the Białowieża Primeval Forest, and they stated that the highest amount of it was found in the strict reserve of Białowieża National Park $-157 \mathrm{~m}^{3} / \mathrm{ha}$. In the current study, this value is taken as the reference point $(100 \%)$. Due to the fact that the samples analyzed in this study come mainly from the strict reserve of Białowieża National Park and the reserves within the area of the Białowieża Primeval Forest, the estimated amount of dead wood for this analysis is the average number calculated from the values given by the authors of the study mentioned above (Table 1). In the case of the other locations, the estimated amount of dead wood was calculated as a percentage of the dead wood in the reference area.

Table 1. Location, legal status, and number of collected samples in the examined areas. PB-Białowieża Primeval Forest, RC—Cisy Staropolskie im. Leona Wyczółkowskiego Nature Reserve, RJ—Jakubowo Nature Reserve, RL—Las Grądowy nad Mogilnicą Nature Reserve, RBB—Bytyńskie Brzęki Nature Reserve, RBG—Brzęki przy Starej Gajówce Nature Reserve, RHG-Huby Grzebieniskie Nature Reserve.

\begin{tabular}{|c|c|c|c|c|c|c|c|}
\hline Area & PB & RC & RJ & RL & RBB & RBG & RHG \\
\hline Location & $\begin{array}{c}\text { northern-east } \\
\text { Poland, } \\
52^{\circ} 46^{\prime} \mathrm{N} \\
23^{\circ} 52^{\prime} \mathrm{E}\end{array}$ & $\begin{array}{c}\text { northern- } \\
\text { west Poland, } \\
53^{\circ} 30^{\prime} \mathrm{N} \\
18^{\circ} 07^{\prime} \mathrm{E}\end{array}$ & $\begin{array}{l}\text { western } \\
\text { Poland, } \\
52^{\circ} 29^{\prime} \mathrm{N} \\
16^{\circ} 16^{\prime} \mathrm{E}\end{array}$ & $\begin{array}{l}\text { western } \\
\text { Poland, } \\
52^{\circ} 28^{\prime} \mathrm{N} \\
16^{\circ} 14^{\prime} \mathrm{E}\end{array}$ & $\begin{array}{l}\text { western } \\
\text { Poland, } \\
52^{\circ} 28^{\prime} \mathrm{N} \\
16^{\circ} 28^{\prime} \mathrm{E}\end{array}$ & $\begin{array}{l}\text { western } \\
\text { Poland, } \\
52^{\circ} 28^{\prime} \mathrm{N} \\
16^{\circ} 29^{\prime} \mathrm{E}\end{array}$ & $\begin{array}{l}\text { western } \\
\text { Poland, } \\
52^{\circ} 27^{\prime} \mathrm{N} \\
16^{\circ} 31^{\prime} \mathrm{E}\end{array}$ \\
\hline Legal status & $\begin{array}{l}\text { national park, } \\
\text { strict nature } \\
\text { reserve and } \\
\text { unprotected } \\
\text { areas }\end{array}$ & $\begin{array}{l}\text { nature } \\
\text { reserve }\end{array}$ & $\begin{array}{l}\text { nature } \\
\text { reserve }\end{array}$ & $\begin{array}{l}\text { nature } \\
\text { reserve }\end{array}$ & $\begin{array}{l}\text { nature } \\
\text { reserve }\end{array}$ & $\begin{array}{l}\text { nature } \\
\text { reserve }\end{array}$ & $\begin{array}{l}\text { nature } \\
\text { reserve }\end{array}$ \\
\hline $\begin{array}{c}\text { Establishment } \\
\text { year }\end{array}$ & 1932 & 1827 & 1959 & 1959 & 1959 & 1959 & 1959 \\
\hline $\begin{array}{l}\text { Age of tree } \\
\text { stand [years] }\end{array}$ & $>150$ & $>150$ & $>150$ & $<100$ & $\sim 100$ & $>100$ & $>80$ \\
\hline Area [ha] & 10,517 & 113.61 & 4.02 & 7.32 & 15.15 & 6.71 & 14.73 \\
\hline $\begin{array}{l}\text { Data } \\
\text { collection } \\
\text { period }\end{array}$ & 1961-2018 & 1992-2019 & 1978-2000 & 1979-2000 & 2002-2004 & 2002-2004 & 2002-2004 \\
\hline $\begin{array}{c}\text { Number of } \\
\text { samples }\end{array}$ & 249 & 979 & 3489 & 2101 & 200 & 285 & 226 \\
\hline $\begin{array}{c}\text { Dead wood } \\
{\left[\mathrm{m}^{3} / \mathrm{ha}\right]}\end{array}$ & 131 & 118 & 47 & 47 & 39 & 39 & 39 \\
\hline $\begin{array}{l}\% \text { of dead } \\
\text { wood in } \\
\text { reference } \\
\text { area }\end{array}$ & 83 & 75 & 30 & 30 & 78 & 78 & 78 \\
\hline References & [4] & [47] & {$[45,47]$} & {$[45,47]$} & [46] & [46] & [46] \\
\hline Figures & S1 & S2 & S3 & S4 & S5 & S6 & S7 \\
\hline
\end{tabular}




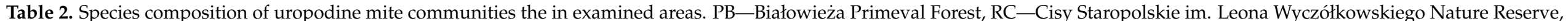

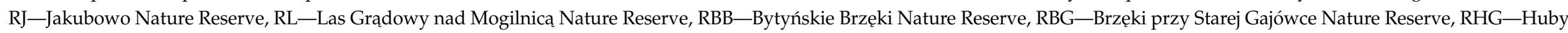

Grzebieniskie Nature Reserve. S—soil, DW—dead wood, “+”-species occurrence. Bold—species which occur only in dead wood.

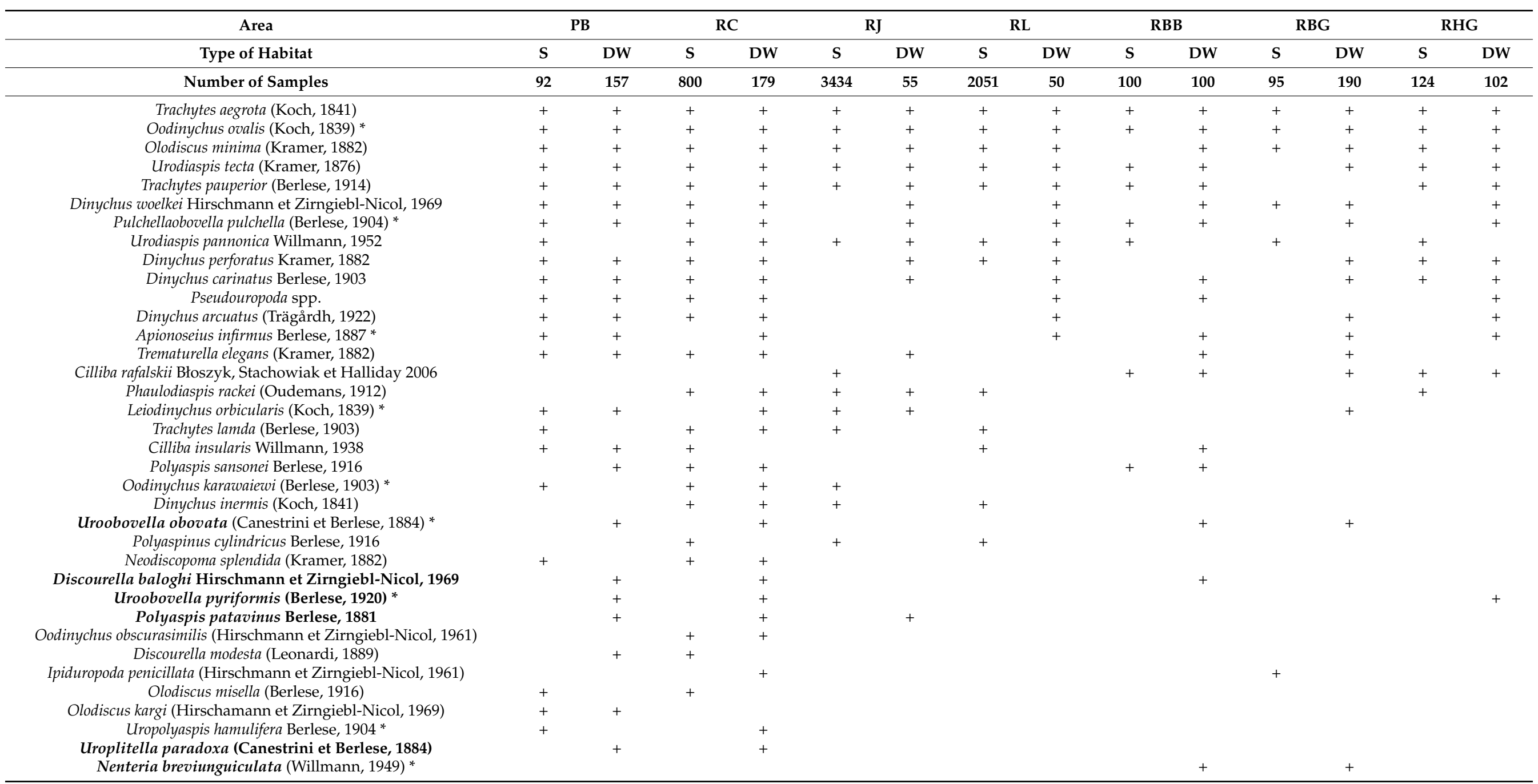


Table 2. Cont.

\begin{tabular}{|c|c|c|c|c|c|c|c|c|c|c|c|c|c|c|}
\hline \multirow{2}{*}{$\begin{array}{c}\text { Area } \\
\text { Type of Habitat }\end{array}$} & \multicolumn{2}{|c|}{ PB } & \multicolumn{2}{|c|}{ RC } & \multicolumn{2}{|c|}{ RJ } & \multicolumn{2}{|c|}{ RL } & \multicolumn{2}{|c|}{ RBB } & \multicolumn{2}{|c|}{ RBG } & \multicolumn{2}{|c|}{ RHG } \\
\hline & S & DW & S & DW & S & DW & $S$ & DW & S & DW & $\mathbf{S}$ & DW & $\mathbf{S}$ & DW \\
\hline Number of Samples & 92 & 157 & 800 & 179 & 3434 & 55 & 2051 & 50 & 100 & 100 & 95 & 190 & 124 & 102 \\
\hline Pseudouropoda tuberosa (Hirschmann et Zirngiebl-Nicol, 1961)* & & & & & & & & & & + & & & & \\
\hline Trichouropoda polytricha (Vitzthum, 1923)* & & + & & & & & & & & & & & & \\
\hline Trichouropoda bipilis (Vitzthum, 1920) & & + & & & & & & & & & & & & \\
\hline Trachyuropoda coccinea (Michael, 1891) & & & & & & & & & & & & + & & \\
\hline Uropoda fumicola Hirschmann et Zirngiebl-Nicol, 1969 & + & & & & & & & & & & & & & \\
\hline Uroplitella conspicua Berlese, 1903 & & & & + & & & & & & & & & & \\
\hline Oplitis stammeri (Hirschmann et Zirgiebl-Nicol, 1961) & & & & + & & & & & & & & & & \\
\hline Oplitis sp. & + & & & & & & & & & & & & & \\
\hline Uroobovella ipidis Hirschmann et Zirngiebl-Nicol, 1962 & & + & & & & & & & & & & & & \\
\hline Uroobovella baloghi Hirschmann et Zirngiebl-Nicol, 1962 & & + & & & & & & & & & & & & \\
\hline Uroobovella similiobovata Hirschmann et Zirgiebl-Nicol, 1962 & & & & + & & & & & & & & & & \\
\hline Uroobovella marginata $($ Koch, 1829$)$ & & + & & & & & & & & & & & & \\
\hline Nenteria stylifera (Berlese, 1904) & & & & & & & & & & & & + & & \\
\hline Dinychura cordieri (Berlese, 1916) & & & & & & & & & & & & & & + \\
\hline Dinychus septentrionalis (Trägårdh, 1943) & & + & & & & & & & & & & & & \\
\hline Dinychus sublaevis (Trägårdh, 1943) & & & + & & & & & & & & & & & \\
\hline Uropoda sp. & & & & & & & & & & & & & & + \\
\hline
\end{tabular}




\section{Results}

\subsection{Uropodina Mite Communities Inhabiting Litter, Soil and Dead Wood Merocenoses in Examined Forest Ecosystems}

In the examined locations the researchers found in total 54 species of Uropodina mites (Table 2). Only one species, that is, T. aegrota occurred both in the soil samples and merocenoses of dead wood in all examined areas. The occurrence of the other species varied depending on the location and environment. Five species were found only in the soil samples from all examined areas, whereas 20 species occurred only in the dead wood merocenoses (Table 2-bold). This suggests that the presence of dead wood merocenoses enriches the species diversity of the Uropodina communities in the examined areas by $37 \%$. As many as 37 species were found in the soil samples, and 27 species in soil and dead wood samples (Figure 1).

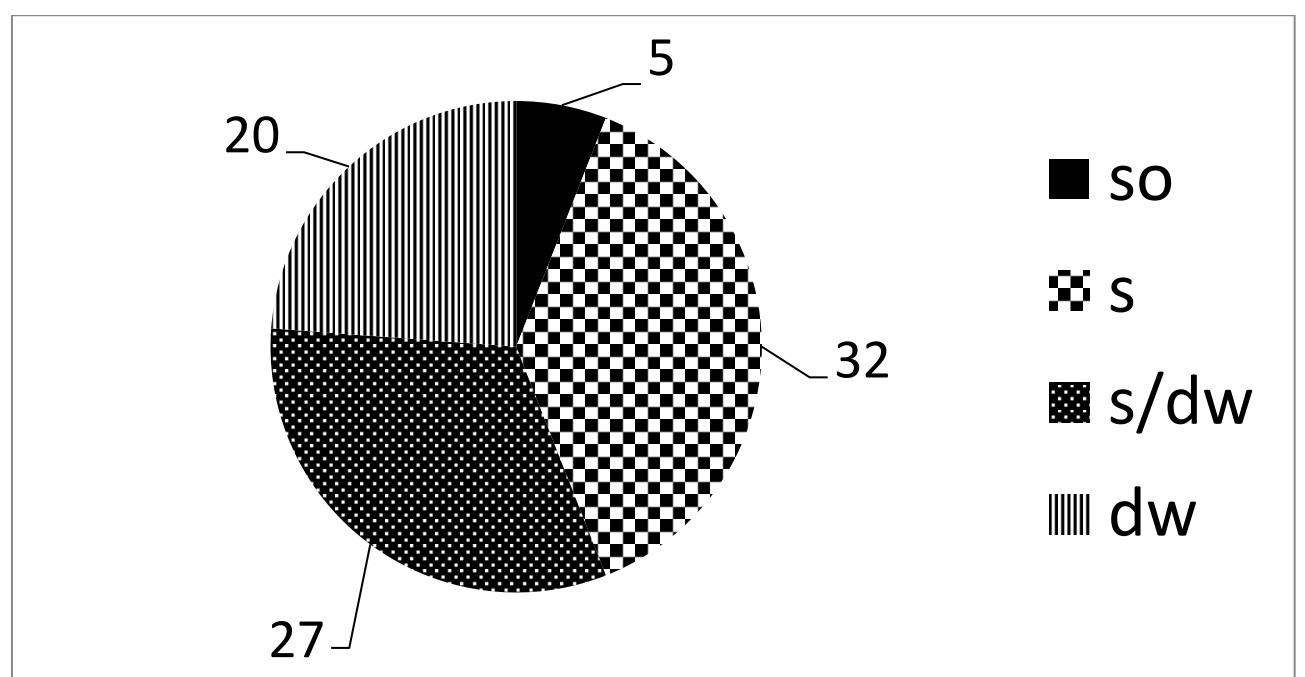

Figure 1. Number of species with different habitat preferences in all examined locations: SOspecies found only in soil, S-species found in soil, S/DW-species found in soil and dead wood, DW-species found only in dead wood and tree hollows.

As for the percentage of the species which occurred only in dead wood in the examined areas, it was the highest in two oak-hornbeam nature reserves in western Poland, that is, in Bytyńskie Brzęki Nature Reserve and Brzęki near Stara Gajówka Nature Reserve (58 and 65\% species of the community) (Table 3). The lowest percentage (32\%) of the species inhabiting only dead wood was recorded in the material from Jakubowo Nature Reserve. Most of the Uropodina species found in the examined locations inhabited litter or soil (they constitute roughly 57\%). Many of them (approx. 42\%) were eurytopic species occurring both in the soil and dead wood samples. The species associated only with dead wood constitute roughly $43 \%$ in the examined locations.

Table 3. Percentage of species with different habitat preferences in examined locations. PB-Białowieża Primeval Forest, RC-Cisy Staropolskie im. Leona Wyczółkowskiego Nature Reserve, RJ-Jakubowo Nature Reserve, RL—Las Grądowy near Mogilnica Nature Reserve, RBB-Bytyńskie Brzęki Nature Reserve, RBG-Brzęki near Stara Gajówka Nature Reserve, RHG—Huby Grzebieniskie Nature Reserve, Ave \pm SD—average \pm Standard Deviation.

\begin{tabular}{ccccccccc}
\hline Habitat/Microhabitat & PB & RC & RJ & RLG & RBB & RBG & RHG & Ave \pm SD \\
\hline soil & 64.9 & 65.8 & 68.4 & 66.7 & 42.1 & 35.3 & 55.6 & $57.0 \pm 13.3$ \\
\hline soil/dead wood & 43.2 & 52.6 & 42.1 & 38.9 & 36.8 & 35.3 & 44.4 & $41.9 \pm 5.8$ \\
\hline dead wood & 35.1 & 34.2 & 31.6 & 33.3 & 57.9 & 64.7 & 44.4 & $43.0 \pm 13.3$ \\
\hline
\end{tabular}




\subsection{Differences in Species Composition in Dead Wood Merocenoses in Examined Locations}

The tabulation in Table A1 shows the results of the zoocenological analysis of the communities inhabiting the dead wood merocenoses in the examined locations. The highest species diversity was recorded in the dead wood samples from Cisy Staropolskie Nature Reserve and the Białowieża Primeval Forest (33 and 29 species respectively). Oodinychus ovalis was eudominant or dominant species and the most frequent species in all examined locations. In Cisy Staropolskie Nature Reserve U. pyriformis (Berlese, 1920) was also a frequent species (category D4). In the Białowieża Primeval Forest, Jakubowo Nature Reserve, Brzęki near Stara Gajówka Nature Reserve D. carinatus was the dominant species. The other species occurred in the analyzed communities in lower numbers and less frequently.

The analysis of species diversity in the Uropodina communities inhabiting dead wood in the examined locations (Figure 2) has revealed that the highest similarity $(80 \%)$ between the communities in Huby Grzebieniskie Nature Reserve and Las Gradowy near Mogilnica Nature Reserve. A similar situation was also observed in the species composition of the communities found in Brzẹki near Stara Gajówka Nature Reserve. A fairly high degree of similarity $(<50 \%)$ was also recorded for the communities in Bytyńskie Brzeki Nature Reserve and the Białowieża Primeval Forest. Finally, the species composition of the communities inhabiting the dead wood merocenoses in Jakubowo and Cisy Staropolskie were considerably different from those in the other locations (and between themselves).

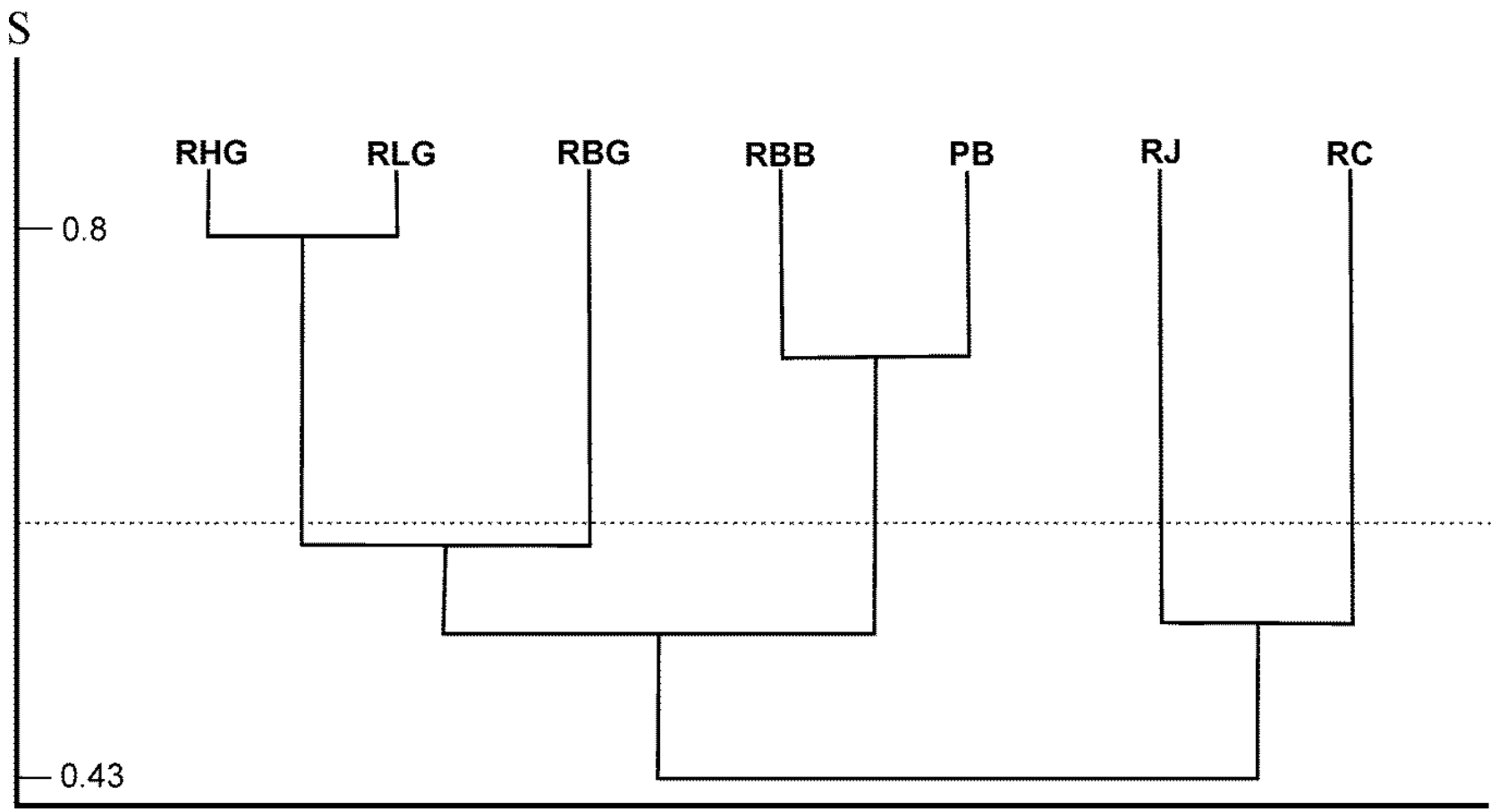

Figure 2. Species similarity (S) of the species composition in Uropodina communities in examined locations: PB—Białowieża Primeval Forest, RC-Cisy Staropolskie im. Leona Wyczółkowskiego Nature Reserve, RJ-Jakubowo Nature Reserve, RLG—Las Grądowy near Mogilnica Nature Reserve, RBB—Bytyńskie Brzęki Nature Reserve, RBG-Brzęki near Stara Gajówka Nature Reserve, RHG—Huby Grzebieniskie Nature Reserve.

\section{Discussion}

The results of the conducted analyses show that the presence of dead wood considerably enriches the overall biodiversity of Uropodina communities in the examined forest ecosystems by about $40 \%$. This in turn means that the presence of dead wood is essential for many mite species to have favorable habitat conditions in a forest ecosystem. Moreover, it is also noteworthy that in the group of the species associated only with dead wood (Table 1), which occurred mainly in the Białowieża Primeval Forest and Cisy Staropolskie im. Leona Wyczółkowskiego Nature Reserve, there are rare and very rare species, which 
according to the updated IUCN criteria [53] have been classified as endangered. Among these species there are O. stammeri, O. franzi, (CR category-Critically Endangered), D. baloghi (EN-Endangered), U. obovata, T. polytricha, Uroplitella paradoxa, and U. conspicua (VU-Vulnerable).

In the examined locations the percentage of species with a strong preference for dead wood habitats was different and it depends on many factors. The two most important among these are the method of forest management, especially the policies regarding dead wood in a given area, and how long the area has been legally protected. Białowieża National Park can be regarded as a model forest ecosystem due to its unique quality of the tree stand, which has retained many characteristics of the primeval forest [38-41], and the fact that the dead wood is stored in large quantities, especially in the legally protected area of the park and reserve [54]. In this location, the overall species diversity had the highest value (37 species, Table 2) and also second as to the Uropodina communities inhabiting dead wood. The same total number of Uropodina species with the highest species diversity was recorded in the communities found in the dead wood samples from Cisy Staropolskie im. Leona Wyczółkowskiego Nature Reserve, which is the oldest Nature Reserve in Poland and the second in Europe as to the legal protection status [41-44]. Similar to the Białowieża Primeval Forest, also in this reserve, dead wood remains in large quantities. What is more interesting, the percentage of the species inhabiting dead wood in the overall number of the species found in the communities in these two locations was not the highest-35.1 (in Białowieża National Park) and 34.2 (in Cisy Staropolskie Nature Reserve) (Table 3). This is due to the fact that the biodiversity in these locations is very high. This can be also observed in the high values of the Maturity Index for the Białowieża Primeval Forest and Cisy Staropolskie Nature Reserve [55]. The Maturity Index (MI) is an indicator based on the life-history traits (so-called r-to-K life strategy) of the species. The Maturity Index was used to evaluate the current of soil quality and it was used for the first time by [56].

In five nature reserves of western Poland examined for the purpose of this study, the amount of dead wood was different in each case (Table 1). In Jakubowo and Las Gradowy until the end of the 1980s of the last century, dead trees were regularly removed from the area of the reserve, and hence the amount of dead wood was very low despite the fact that the tree standing in Jakubowo is now over 150 years old. For this reason, during the research period before 1990, the percentage of the species associated with dead wood was very low [2,57]. This situation changed at the end of the 1990s when the law of environment protection had changed and dead wood was left untouched and the percentage of the species inhabiting dead wood merocenoses is apparently high. The communities of Uropodina mites inhabiting dead wood in these reserves consist mainly of common species, most of which also inhabit the soil. Higher species diversity was observed in the dead wood merosenoses of the other three reserves in Wielkopolska (Bytyńskie Brzęki Nature Reserve, Brzęki near Stara Gajówka Nature Reserve, Huby Grzebieniskie Nature Reserve), where the research was also conducted in the period when large quantities of dead wood (mainly in the form of windthrow) were left. In these reserves, there are also rare species that occur only in dead wood, such as P. tuberosa and T. coccinea (Table A1), to name but a few. The Uropodina communities in these three locations also turned out to be similar regarding their species composition. What is more interesting, the Uropodina communities inhabiting dead wood in Bytyńskie Brzęki Nature Reserve are very similar to the communities inhabiting the dead wood merocenoses in the Białowieża Primeval Forest, which can stem from the fact that in both locations most of the dead wood comes from oaks. The influence of the tree species on Uropodina communities inhabiting dead wood will be the major focus of another study in the future.

Napierała and Błoszyk [3] showed that Uropodina communities inhabiting unstable microhabitats, including dead wood, can considerably differ from communities inhabiting soil. The differences can be observed not only in the species composition but also in the structure of the community in each type of habitat. Uropodina communities inhabiting merocenoses are often predominated by one or two species, which constitute more than 
$50 \%$ of the entire community, in contrast to those inhabiting soil, where there are usually no eudominants. The results presented in this study support this observation because in all of the examined communities inhabiting dead wood in the seven selected locations one species was evidently dominant (O. ovalis), or two species at most, whereas the other species were less abundant.

Huhta et al. [1] studied the importance of dead wood for Oribatida and Mesostigmata in boreal forests in Finland and among 13 species of Uropodina they found, only five species occurred in the soil and eight in the dead wood samples. All of the found species, except Uroobovella vinicolora (Vitzthum 1926) and Uropoda cassidea (Hermann 1804), were also found in our material. This conforms our results and observations and proves the great importance of dead wood for mites from this group. These results also corroborate the fact that dead wood considerably increases the overall biodiversity of forest ecosystems.

A research study on oribatid mites (Oribatida) [58] has also revealed that remaining and rotting tree trunks should be regarded as a different type of habitat for mites living in the soil. According to these researchers, dead wood merocenoses constitute a kind of microhabitat islands, though most of the species inhabiting dead wood can also be found in the litter. In 2020 Niedbała et al. [5] published a study on communities of Ptyctimous mites in the Białowieża Primeval Forest, where 20 out of 22 species forming communities of these mites occurred in soil, and only one of them, Atropacarus (Atropacarus) csiszarae (Balogh et Mahunka, 1979), was not found in the samples of dead wood. Only two species (Protoribotria oligotricha (Märkel, 1963) and Phthiracarus opacus (Niedbała, 1986)) out of 21 species found in the dead wood samples did not occur in the soil samples. Similar research into ptyctimous mites was carried out in Cisy Staropolskie Nature Reserve in the period 2018-2019 (unpublished data). The obtained results were very similar, though all species found in the soil occurred also in the merocenoses of dead wood. This in turn implies that the habitat preferences of ptyctimous mites are less restricted, and these mites are less picky in making their habitat choice than Uropodina mites. However, the studies on the importance of dead wood for Oribatida are not unequivocal because the observations made by some authors [59-61] show that oribatid communities in dead wood differ from those inhabiting soil.

The mechanism of colonization of dead wood microhabitats in the case of Oribatida, which have no capabilities of passive dispersion, and Uropodina, which can spread by means of phoresy, is therefore different. Oribatid mites usually inhabit the nearest merocenoses of dead wood by themselves. Probably for this reason species composition of oribatid mite communities in dead wood merocenoses is very similar to that observed in communities inhabiting soil. In the case of Uropodina mites, which are sometimes carried by insects at long distances, the species can be absent in communities inhabiting soil in close vicinity. It was proved that these mites, especially O. ovalis and P. pulchella (Berlese, 1904), use centipedes (mainly Lithobius forficatus Linné, 1758) to disperse at short distances $[33,34]$.

\section{Conclusions}

According to Błoszyk [20], over 1/3 of Uropodina mites in Poland are steno- or oligotopic species. On the other hand, eurytopic species, which live in different habitats, constitute only $25 \%$. This proves that Uropodina mites have more restricted and more specific environment and microhabitat preferences. In the case of these mites leaving dead wood or dead tree trunks with hollows in forest ecosystems considerably increases the overall number of natural niches, and therefore the number of Uropodina species and their abundance as well as many other groups of invertebrates. The obtained results can be another reason for introducing changes in forest management regulations, especially those regarding dead wood, which should not be considered as the habitat of pests or a source of cheap timber, but as an important component of the ecosystem. 
Author Contributions: Conceptualization, J.B., A.N.; Methodology, A.N., J.B.; Software, J.B.; Validation, J.B., A.N., M.Z.; Formal Analysis, J.B., A.N., M.Z.; Investigation, J.B., A.N., S.K., T.R.; Resources, J.B., A.N., T.R.; Data Curation, J.B.; Writing-Original Draft Preparation, J.B., A.N., S.K.; WritingReview and Editing, A.N., S.K.; Visualization, J.B., A.N.; Supervision, A.N.; Project Administration, J.B.; Funding Acquisition, J.B. and A.N. All authors have read and agreed to the published version of the manuscript.

Funding: This work was possible due to financial support from the Department of General Zoology received for a Ph.D. project carried out by Michał Zacharyasiewicz, M.A.

Institutional Review Board Statement: Not applicable.

Data Availability Statement: Not applicable.

Acknowledgments: The authors of the study are grateful to all who collected dead wood samples which are now stored in the AMU Nature Collections of the Faculty of Biology in Poznań, especially Monika Markowicz, M.A. and Bartosz Labijak, M.A. The authors would like to thank hab. Zbigniew Adamski for taking SEM images.

Conflicts of Interest: The authors declare no conflict of interest.

\section{Appendix A}
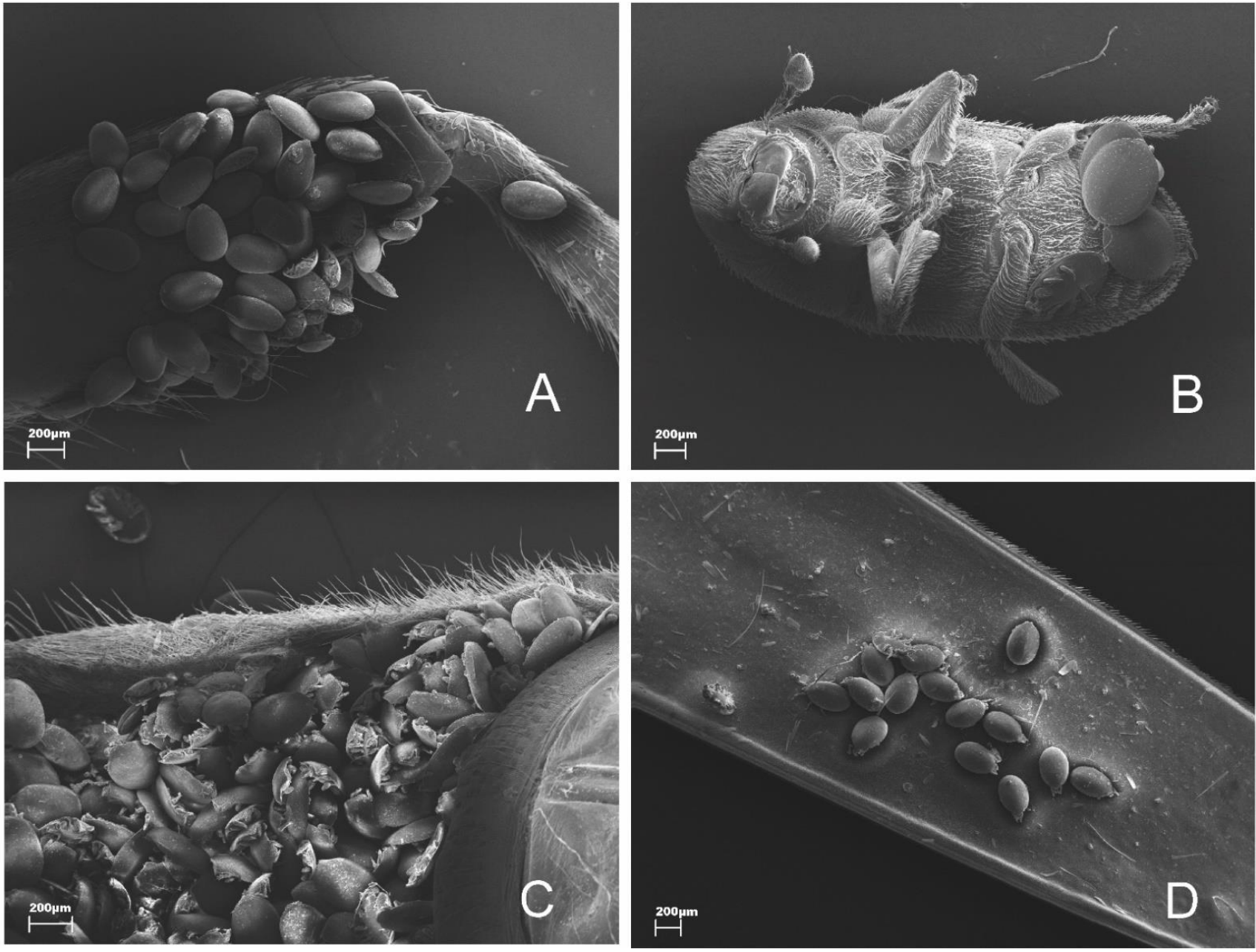

Figure A1. SEM micrographs of phoretic deutonymphs of Uropodina mites carried by on different parts of the insect: on the leg of a family Cerambycidae representative (A), on bark beetle (Scolytinae) (B), on abdomen (C), on subelytra (D). 
Table A1. Species composition and structure of Uropodine mites communities the in dead wood in the examined areas: PB—Białowieża Primeval Forest, RC—Cisy Staropolskie im. Leona Wyczółkowskiego Nature Reserve, RJ-Jakubowo Nature Reserve, RL—Las Grądowy nad Mogilnica Nature Reserve, RBB—Bytyńskie Brzęki Nature Reserve, RBG—Brzęki przy Starej Gajówce Nature Reserve, RHG—Huby Grzebieniskie Nature Reserve. S—soil, DW—dead wood; D—dominance, $\mathrm{F}$-frequency. Bold—dominant and the most frequent species.

\begin{tabular}{|c|c|c|c|c|c|c|c|c|c|c|c|c|c|c|}
\hline \multirow{2}{*}{$\begin{array}{c}\text { Area } \\
\text { Species }\end{array}$} & \multicolumn{2}{|c|}{ PB } & \multicolumn{2}{|c|}{ RC } & \multicolumn{2}{|c|}{ RJ } & \multicolumn{2}{|c|}{ RL } & \multicolumn{2}{|c|}{ RBB } & \multicolumn{2}{|c|}{ RBG } & \multicolumn{2}{|c|}{ RHG } \\
\hline & D & $F$ & D & $F$ & D & $\mathbf{F}$ & D & $F$ & D & $\mathrm{F}$ & D & $\mathrm{F}$ & D & $F$ \\
\hline T. aegrota & D2 & F3 & D1 & F2 & D2 & F3 & D2 & F4 & D2 & F3 & D2 & F2 & D2 & F4 \\
\hline O. ovalis & D5 & F4 & D4 & F3 & D5 & F5 & D5 & F5 & D5 & F5 & D5 & F4 & D5 & F5 \\
\hline O. minima & D1 & $\mathrm{F} 1$ & D1 & F2 & D1 & $\mathrm{F} 2$ & D1 & F3 & D2 & F2 & D2 & F2 & D1 & $\mathrm{F} 2$ \\
\hline U. tecta & D1 & F2 & D1 & F2 & D1 & $\mathrm{F} 1$ & D1 & $\mathrm{F} 1$ & D1 & F3 & D3 & F2 & D1 & F2 \\
\hline T. pauperior & D1 & $\mathrm{F} 1$ & D1 & F1 & D1 & $\mathrm{F} 2$ & D1 & F2 & D1 & $\mathrm{F} 1$ & & & D1 & $\mathrm{F} 2$ \\
\hline D. woelkei & D1 & F1 & D1 & $\mathrm{F} 1$ & D1 & F2 & D3 & F2 & D1 & F2 & D2 & F2 & D2 & F2 \\
\hline P. pulchella & D3 & F2 & D2 & F2 & D1 & F1 & D1 & $\mathrm{F} 1$ & D3 & F2 & D2 & $\mathrm{F} 1$ & D3 & F3 \\
\hline U. pannonica & & & D1 & $\mathrm{F} 1$ & D1 & $\mathrm{F} 1$ & D1 & $\mathrm{F} 1$ & & & & & & \\
\hline D. perforatus & D1 & F1 & D1 & F1 & D2 & F1 & D1 & $\mathrm{F} 1$ & & & D1 & $\mathrm{F} 1$ & D1 & F1 \\
\hline D. carinatus & D4 & F2 & $\mathrm{D} 2$ & $\mathrm{~F} 2$ & D4 & F4 & D3 & F3 & D1 & F2 & D4 & F2 & D1 & $\mathrm{F} 2$ \\
\hline Pseudouropoda spp. & D1 & $\mathrm{F} 1$ & D1 & $\mathrm{F} 1$ & & & D1 & $\mathrm{F} 1$ & D1 & $\mathrm{F} 1$ & & & D1 & $\mathrm{F} 1$ \\
\hline D. arcuatus & D2 & F2 & D1 & F2 & & & D1 & $\mathrm{F} 1$ & & & D1 & $\mathrm{F} 1$ & D1 & $\mathrm{F} 1$ \\
\hline A. infirmus & D1 & F1 & D1 & F1 & & & D1 & $\mathrm{F} 1$ & D1 & F1 & D1 & F1 & D1 & $\mathrm{F} 1$ \\
\hline T.elegans & D1 & $\mathrm{F} 1$ & $\mathrm{D} 2$ & F2 & D1 & F1 & & & D1 & $\mathrm{F} 1$ & D1 & $\mathrm{F} 1$ & & \\
\hline C. rafalskii & & & & & & & & & D1 & $\mathrm{F} 1$ & D1 & $\mathrm{F} 1$ & D1 & F1 \\
\hline P. rackei & & & D1 & $\mathrm{F} 1$ & D1 & F1 & & & & & & & & \\
\hline L. orbicularis & D1 & $\mathrm{F} 1$ & D1 & $\mathrm{F} 1$ & D1 & F1 & & & & & D1 & $\mathrm{F} 1$ & & \\
\hline T. lamda & & & D1 & $\mathrm{F} 1$ & & & & & & & & & & \\
\hline C. insularis & D1 & $\mathrm{F} 1$ & & & & & & & D1 & $\mathrm{F} 1$ & & & & \\
\hline P. sansonei & D1 & $\mathrm{F} 1$ & D1 & F1 & & & & & D1 & $\mathrm{F} 1$ & & & & \\
\hline O. karawaiewi & & & D1 & $\mathrm{F} 1$ & & & & & & & & & & \\
\hline D. inermis & & & D1 & $\mathrm{F} 1$ & & & & & & & & & & \\
\hline U. obovata & D1 & $\mathrm{F} 1$ & D1 & F1 & & & & & D1 & $\mathrm{F} 1$ & D1 & F1 & & \\
\hline \multicolumn{15}{|l|}{ P. cylindricus } \\
\hline N. splendida & & & D1 & F1 & & & & & & & & & & \\
\hline D. baloghi & D1 & F1 & D3 & F2 & & & & & D1 & $\mathrm{F} 1$ & & & & \\
\hline P. pyriformis & D1 & $\mathrm{F} 1$ & D4 & $\mathrm{F} 1$ & & & & & & & & & D1 & F1 \\
\hline P. patavinus & D1 & F1 & D1 & F1 & D1 & F1 & & & & & & & & \\
\hline O. obscurasimilis & & & D1 & F1 & & & & & & & & & & \\
\hline D. modesta & D1 & F1 & & & & & & & & & & & & \\
\hline I. penicillata & & & D1 & $\mathrm{F} 1$ & & & & & & & & & & \\
\hline \multicolumn{15}{|l|}{ O. misella } \\
\hline O. kargi & D1 & $\mathrm{F} 1$ & & & & & & & & & & & & \\
\hline U. hamulifera & & & D1 & F1 & & & & & & & & & & \\
\hline U. paradoxa & D1 & $\mathrm{F} 1$ & D1 & $\mathrm{F} 1$ & & & & & & & & & & \\
\hline N. breviunguiculata & & & & & & & & & D1 & F1 & D1 & F1 & & \\
\hline
\end{tabular}


Table A1. Cont.

\begin{tabular}{|c|c|c|c|c|c|c|c|c|c|c|c|c|c|c|}
\hline \multirow{2}{*}{$\begin{array}{c}\text { Area } \\
\text { Species }\end{array}$} & \multicolumn{2}{|c|}{ PB } & \multicolumn{2}{|c|}{ RC } & \multicolumn{2}{|c|}{ RJ } & \multicolumn{2}{|c|}{$\mathbf{R L}$} & \multicolumn{2}{|c|}{ RBB } & \multicolumn{2}{|c|}{ RBG } & \multicolumn{2}{|c|}{ RHG } \\
\hline & $\mathrm{D}$ & $\mathbf{F}$ & D & $\mathbf{F}$ & D & $\mathbf{F}$ & D & $\mathbf{F}$ & $\mathrm{D}$ & $\mathbf{F}$ & $\mathbf{D}$ & $\mathbf{F}$ & D & $\mathbf{F}$ \\
\hline P. tuberosa & & & & & & & & & D1 & F1 & & & & \\
\hline T. polytricha & D1 & F1 & & & & & & & & & & & & \\
\hline T. bipilis & D1 & $\mathrm{F} 1$ & & & & & & & & & & & & \\
\hline T. coccinea & & & & & & & & & & & D1 & F1 & & \\
\hline \multicolumn{15}{|l|}{ U. fumicola } \\
\hline U. conspicua & & & D1 & $\mathrm{F} 1$ & & & & & & & & & & \\
\hline O. stammeri & & & D1 & $\mathrm{F} 1$ & & & & & & & & & & \\
\hline O. franzi & & & D1 & F1 & & & & & & & & & & \\
\hline \multicolumn{15}{|l|}{ Oplitis sp. } \\
\hline U. ipidis & D1 & $\mathrm{F} 1$ & & & & & & & & & & & & \\
\hline U. baloghi & D1 & $\mathrm{F} 1$ & & & & & & & & & & & & \\
\hline U. similiobovata & & & D1 & $\mathrm{F} 1$ & & & & & & & & & & \\
\hline U. marginata & D1 & $\mathrm{F} 1$ & & & & & & & & & & & & \\
\hline N. stylifera & & & & & & & & & & & D1 & $\mathrm{F} 1$ & & \\
\hline D. cordieri & & & & & & & & & & & & & D1 & F1 \\
\hline D. septentrionalis & D1 & $\mathrm{F} 1$ & & & & & & & & & & & & \\
\hline \multicolumn{15}{|l|}{ D. sublaevis } \\
\hline Uropoda sp. & & & & & & & & & & & & & D1 & F1 \\
\hline Number of specimens & \multicolumn{2}{|c|}{2053} & \multicolumn{2}{|c|}{2826} & \multicolumn{2}{|c|}{847} & & & \multicolumn{2}{|c|}{1241} & \multicolumn{2}{|c|}{1169} & \multicolumn{2}{|c|}{2081} \\
\hline Number of species & \multicolumn{2}{|c|}{29} & \multicolumn{2}{|c|}{33} & \multicolumn{2}{|c|}{14} & & & \multicolumn{2}{|c|}{18} & \multicolumn{2}{|c|}{17} & \multicolumn{2}{|c|}{16} \\
\hline
\end{tabular}

\section{References}

1. Huhta, V.; Siira-Pietikäinen, A.; Penttinen, R. Importance of dead wood for soil mite (Acarina) communities in boreal old-growth forests. Soil Org. 2012, 84, 499-512.

2. Błoszyk, J.; Napierała, A.; Markowicz-Rucińska, M. Zróżnicowanie zgrupowań Uropodina (Acari: Mesostigmata) wybranych rezerwatów Wielkopolski. Parki nar. Rez. Przyr. 2003, 22, 285-298.

3. Napierała, A.; Błoszyk, J. Unstable microhabitats (merocenoses) as specific habitats of Uropodina mites (Acari: Mesostigmata). Exp. Appl. Acarol. 2013, 60, 163-180. [CrossRef]

4. Napierała, A.; Konwerski, S.; Gutowski, J.M.; Błoszyk, J. Species diversity of Uropodina communities (Acari: Parasitiformes) in soil and selected microhabitats in the Białowieża Primeval Forest. In Mites (Acari) of the Białowieża Primeval Forest, 1st ed.; Błoszyk, J., Napierała, A., Eds.; Kontekst: Poznań, Poland, 2020; pp. 11-60.

5. Niedbała, W.; Błoszyk, J.; Gutowski, J.M.; Konwerski, S.Z.; Napierała, A. A characteristic of communites of ptyctimous mites (Acari: Acariformes: Oribatida) in the Białowieża Primeval Forest, Central Europe. In Mites (Acari) of the Białowieża Primeval Forest, 1st ed.; Błoszyk, J., Napierała, A., Eds.; Kontekst: Poznań, Poland, 2020; pp. 61-127.

6. Wielkoobszarowa inwentaryzacja stanu lasów w Polsce. Available online: https://www.bdl.lasy.gov.pl/portal/Media/Default/ Publikacje/WISL2016_2020.pdf (accessed on 31 July 2021).

7. Siitonen, J. Microhabitats. In Biodiversity in Dead Wood, 1st ed.; Stokland, J.N., Siitonen, J., Jonsson, B.G., Eds.; Cambridge University Press: Cambridge, UK, 2012; pp. 150-182.

8. Siitonen, J.; Stokland, J.N. Tree size. In Biodiversity in Dead Wood, 1st ed.; Stokland, J.N., Siitonen, J., Jonsson, B.G., Eds.; Cambridge University Press: Cambridge, UK, 2012; pp. 183-193.

9. Stokland, J.N.; Siitonen, J. Species diversity of saproxylic organisms. In Biodiversity in Dead Wood, 1st ed.; Stokland, J.N., Siitonen, J., Jonsson, B.G., Eds.; Cambridge University Press: Cambridge, UK, 2012; pp. 248-274.

10. Gutowski, J.M.; Bobiec, A.; Pawlaczyk, P.; Zub, K. Drugie Życie Drzewa; WWF: Warszawa, Poland, 2004; 245p.

11. Stokland, J.N.; Siitonen, J.; Bengt, G.J. Dead wood in natural forest. In Biodiversity in Dead Wood, 1st ed.; Cambridge University Press: Cambridge, UK, 2012; 301p.

12. Ulyshen, M.D. Saproxylic Insects: Diversity, Ecology and Conservation, 1st ed.; Springer: Athens, GA, USA, 2018; 904p. 
13. Siitonen, J. Decaying wood and saproxylic Coleoptera in two old spruce forests: A comparison based on two sampling methods. Ann. Zool. Fenn. 1994, 31, 89-95.

14. Tikkanen, O.-P.; Martikainen, P.; Hyvärinen, E.; Junninen, K.; Kouki, J. Red-listed boreal forest species of Finland: Associations with forest structure, tree species, and decaying wood. Ann. Zool. Fenn. 2006, 43, 373-383.

15. Andersson, L.I.; Hytteborn, H. Bryophytes and decaying wood: A comparison between managed and natural forest. Holarctic Ecol. 1991, 14, 121-130. [CrossRef]

16. Lindblad, I. Wood-inhabiting fungi on fallen logs of Norway spruce: Relations to forest management and substrate quality. Nord. J. Bot. 1998, 18, 243-255. [CrossRef]

17. Siepel, H.; de Ruiter-Dijkman, E.M. Feeding guilds of oribatid mites based on their carbohydrase activities. Soil Biol. Biochem. 1993, 25, 1491-1498. [CrossRef]

18. Erdmann, G.; Otte, V.; Langel, R.; Scheu, S.; Maraun, M. The trophic structure of bark-living oribatidmite communities analysed with stable isotopes $(15 \mathrm{~N}, 13 \mathrm{C})$ indicates strong niche differentiation. Exp. Appl. Acarol. 2007, 41, 1-10. [CrossRef] [PubMed]

19. Ito, Y. Predation by manure-inhabiting mesostigmatids (Acarina: Mesostigmata) on some free-living nematodes. Appl. Ent. Zool. 1971, 6, 51-56. [CrossRef]

20. Karg, W. Acari (Acarina) Milben, Unterordnung Parasitiformes (Anactinochaeta). Uropodina Kramer, Schildkrötenmilben. In Die Tierwelt Deutschlands und der Angrenzenden Meeresteile; Senglaub, K., Hannemann, H.-J., Schumann, H., Eds.; Teil.-Gustav Fischer Verlag: Jena, Thuringia, 1989; Volume 67, pp. 1-203.

21. Karg, W. Acari (Acarina) Milben, Parasitiformes (Anactinochaeta) Cohors Gamasina Leach: Raubmilben. In Zoologisches Museum Berlin, 1st ed.; Dahl, F., Ed.; Die Tierwelt Deutschlands und der angrenzenden Meeresteilem, 59; Teil.-Gustav Fischer Verlag: Jena, Thuringia, 1993; pp. 1-523.

22. Koehler, H. Mesostigmata (Gamasida, Uropodina), efficient predators in agroecosysytems. Agric. Ecosyst. Environ. 1997, 62, 105-117. [CrossRef]

23. Koehler, H. Predatory mites (Gamasida, Mesostigmata). Agric. Ecosyst. Environ. 1999, 74, 395-410. [CrossRef]

24. Faasch, H. Beitrag zur Biologie der einheimischen Uropodiden Uroobovella marginata (C. L. Koch 1839) und Uropoda orbicularis (O. F. Müller 1776) und experimentelle Analyse ihres Phoresieverhaltens. Zool. Jb. Syst. Bd. 1967, 94, 521-608.

25. El-Banhawy, E.M.; El-Borolossy, M.A.; El-Sawaf, B.M.; Afia, S.I. Biological aspects and feeding behaviour of the predacious soil mite Nenteria hypotrichus (Uropodina: Uropodidae). Acarology 1997, 38, 356-360.

26. Athias-Binche, F. Etude quantitative des Uropodides (Acariens: Anactinotriches) d'un arbre mort de la Hetraie de La Massane. 1. Caracteres generaux du peuplement. Vie Et Mileu 1977, 27, 157-175.

27. Athias-Binche, F. Etude quantitative des Uropodides (Acariens: Anactinotriches) d'un arbre mort de la Hetraie de La Massane. 2. Elemenet demographiques d'une population d'Allodinychus flagelliger (Berlese, 1910). Vie Et Mileu 1979, 28-29, 35-60.

28. Błoszyk, J. Fauna Uropodina (Acari: Mesostigmata) spróchniałych pni drzew i dziupli w Polsce. Zesz. Probl. Post. Nauk Roln. 1990, 373, 217-235.

29. Athias-Binche, F. La Phoresie Chez les Acariens. Aspects Adapttifs et Evolutifs; Presses de l'Universite de Perpignan: Perpignan, France, 1994; 179p.

30. Błoszyk, J. Geograficzne i Ekologiczne Zróżnicowanie Zgrupowań Roztoczy z Kohoryty Uropodina (Acari: Mesostigmata) w Polsce: Uropodina Lasów Grądowych (Carpinion betuli); Kontekst: Poznań, Poland, 1999; 245p.

31. Bajerlein, D.; Błoszyk, J. Two cases of hyperphoresy in mesostigmatic mites (Acari: Gamasida; Uropodidae, Macrochelidae). Biol. Lett. 2003, 40, 135-136.

32. Bajerlein, D.; Błoszyk, J. Phoresy of Uropoda orbicularis (Acari: Mesostigmata) by beetles (Coleoptera) associated with catlle dung in Poland. Eur. J. Entomol. 2004, 101, 185-188. [CrossRef]

33. Błoszyk, J.; Klimczak, J.; Leśniewska, M. Phoretic relationships between Uropodina (Acari: Mesostigmata) and centipedes (Chilopoda) as an example of evolutionary adaptation of mites to temporary microhabitats. Eur. J. Entomol. 2006, 103, 699-707. [CrossRef]

34. Napierała, A.; Książkiewicz, Z.; Leśniewska, M.; Gwiazdowicz, D.J.; Mądra, A.; Błoszyk, J. Phoretic relationships between uropodid mites (Acari: Mesostigmata) and centipedes (Chilopoda) in urban agglomeration areas. Int. J. Acarol. 2015, 41, 250-258. [CrossRef]

35. Konwerski, S.; Gutowski, J.M.; Książkiewicz-Parulska, Z.; Błoszyk, J. Repeatability of the phoretic relationships between mites of the genus Trichouropoda Berlese (Parasitiformes: Uropodina) and longhorn beetles of the genus Tetropium Kirby (Coleoptera: Cerambycidae) in Białowieża Primeval Forest, Central Europe. Int. J. Acarol. 2017, 43, 612-621. [CrossRef]

36. Konwerski, S.; Gutowski, J.; Błoszyk, J. Analysis of the phoretic relationships between mites of the genus Trichouropoda Berlese (Parasitiformes: Uropodina) and the longhorn beetle Plagionotus detritus (Linnaeus). Int. J. Acarol. 2019, 45, 29-40. [CrossRef]

37. Konwerski, S.; Gutowski, J.; Błoszyk, J. Patterns of Distribution of Phoretic Deutonymphs of Uropodina on Longhorn Beetles in Białowieża Primeval Forest, Central Europe. Diversity 2020, 12, 239. [CrossRef]

38. Faliński, J.B. Vegetation Dynamics in Temperate Lowland Primeval Forest. Ecological Studies in Białowieża Forest, 1st ed.; Dr. W. Junk Publishers: Dordrecht, The Netherlands, 1986; pp. 1-537.

39. Bobiec, A.; Burgt, H.; Meijer, K.; Zuyderduyn, C.; Haga, J.; Vlaanderen, B. Rich deciduous forests in Białowieża as a dynamic mosaic of developmental phases: Premises for nature conservation and restoration management. Forest Ecol. Manag. 2000, 130, 159-175. [CrossRef] 
40. Kujawa, A.; Orczewska, A.; Falkowski, M.; Blicharska, M.; Bohdan, A.; Buchholz, L.; Chylarecki, P.; Gutowski, J.M.; Latałowa, M.; Mysłajek, R.W.; et al. The Białowieża Forest-A UNESCO Natural Heritage Site-Protection priorities. For. Res. Pap. 2016, 77, 302-323. [CrossRef]

41. Jaroszewicz, B.; Cholewińska, O.; Gutowski, J.M.; Samojlik, T.; Zimny, M.; Latałowa, M. Białowieża Forest - a relic of the high naturalness of European forests. Forests 2019, 10, 849. [CrossRef]

42. Myczkowski, S. Zespoły leśne rezerwatu cisowego “Wierzchlas". Ochrona Przyrody 1961, 27, 91-107.

43. Boiński, M. Szata roślinna Borów Tucholskich; PWN: Warszawa, Poland, 1985; 107p.

44. Błoszyk, J.; Krysiak, D. Uropodina (Acari: Mesostigmata) rezerwatu “Cisy Staropolskie im. Leona Wyczółkowskiego" w Wierzchlesie. Park. Nar. Rez. Przy. 2000, 19, 115-121.

45. Napierała, A.; Labijak, B.; Skwierczyński, F.; Konwerski, S.; Błoszyk, J. Influence of habitat type and natural disturbances on uropodine mite communities (Acari: Mesostigmata: Uropodina) in oak hornbeam forests in Central Europe. Int. J. Acarol. 2014, 41, 41-52. [CrossRef]

46. Błoszyk, J.; Markowicz, M.; Labijak, B.; Skwierczyński, F.; Napierała, A. Microgeographic diversity of Uropodina (Acari: Mesostigmata) communities in dead wood and tree hollows. Redia 2015, 98, 3-12.

47. Błoszyk, J.; Napierała, A. Community structure of mesofauna in the light of qualitative and quantitative research on soil mites. Eur. J. Biol. Res. 2018, 8, 252-262.

48. Hirschmann, W.; Zirngiebl-Nicol, I. Gangsystematic der Parasitiformes. Acarol. Schr. Für Vgl. Milbenkunde 1961, 4, 1-41.

49. Błoszyk, J. Uropodina Polski (Acari: Mesostigmata). Ph.D. Thesis, Adam Mickiewicz University, Poznań, Poland, 1983 ; p. 543.

50. Karg, W. Acari (Acarina) Milben, Unterordnung Parasitiformes (Anactinochaeta). Uropodina Kramer Schildkrötenmilben. Tierwelt Deutsch. 1989, 67, 1-203.

51. Mašan, P. Mites of the cohort Uropodina (Acarina, Mesostigmata) in Slovakia, 1st ed.; Annotationes zoologicae et botanicae: Bratislava, Slovakia, 2001; 320p.

52. Magurran, A.E. Measuring Biological Diversity; Blackwell Publishing: Oxford, UK, 2004; 256p.

53. Napierała, A.; Książkiewicz-Parulska, Z.; Błoszyk, J. A Red List of mites from the suborder Uropodina (Acari: Parasitiformes) in Poland. Exp. Appl. Acarol. 2018, 75, 467-490. [CrossRef] [PubMed]

54. Kuberski, Ł.; Paluch, R.; Kraszewski, B.; Zin, E.; Stereńczak, K. Zasoby Martwego Drewna w Puszczy Białowieskiej na Podstawie Aktualnej Inwentaryzacji na Stałych Powierzchniach Badawczych, Instytut Badawczy Leśnictwa. Available online: http:/ / www. forbiosensing.pl/documents/20182/48898/LK+ref/e3c721de-6bcc-408b-830c-568d72e2d835 (accessed on 4 August 2021).

55. Napierała, A.; Błoszyk, J. The maturity index for Uropodina (Acari: Mesostigmata) communities as an indicator of human-caused disturbance in selected forest complexes of Poland. Exp. Appl. Acarol. 2021, 83, 475-491. [CrossRef] [PubMed]

56. Bongers, T. The maturity index: An ecological measure of environmental disturbance based on nematodes species composition. Oecologia 1990, 83, 14-19. [CrossRef]

57. Napierała, A. Struktura Zgrupowań i Rozkład Przestrzenny Uropodina (Acari: Mesostigmata) w Wybranych Kompleksach Leśnych Wielkopolski. Ph.D. Thesis, Adam Mickiewicz University, Poznań, Poland, 2008.

58. Skubała, P.; Duras, M. Do decaying logs represent habitat islands? Oribatid mite communities in dead wood. Ann. Zool. 2008, 58, 453-466. [CrossRef]

59. Lindo, Z.; Winchester, N.N. A comparison of microarthropod assemblages with emphasis on oribatid mites in canopy suspended soil and forest floors associated with ancient western red cedar trees. Pedobiologia 2006, 50, 31-41. [CrossRef]

60. Siira-Pietikäinen, A.; Penttinen, R.; Huhta, V. Oribatid mites (Acari: Oribatida) in boreal forest floor and decaying wood. Pedobiologia 2008, 52, 111-118. [CrossRef]

61. Déchêne, A.D.; Buddle, C.M. Decomposing logs increase oribatid mite assemblage diversity in mixedwood boreal forest. Biodivers. Conserv. 2010, 19, 237-256. [CrossRef] 